\title{
Habitat associations of birds at Mara Naboisho Conservancy, Kenya
}

\author{
Ara Monadjem $^{\mathrm{a}, \mathrm{b} *}$ and Munir Z. Virani ${ }^{\mathrm{c}}$ \\ ${ }^{a}$ All Out Africa Research Unit, Department of Biological Sciences, University of Swaziland, Private Bag 4, \\ Kwaluseni, Swaziland \\ ${ }^{b}$ Mammal Research Institute, Department of Zoology \& Entomology, University of Pretoria, Private Bag 20, \\ Hatfield 0028, \\ Pretoria, South Africa \\ ${ }^{c}$ The Peregrine Fund, 5668 West Flying Hawk Lane, Boise, Idaho 83709, U.S.A \& Ornithology Section, National \\ Museums of Kenya, P.O Box 40658-00100, Nairobi Kenya \\ *Corresponding author, e-mail: ara@uniswa.sz
}

Habitat associations of birds were quantified through fixed-radius timed bird counts at Mara Naboisho Conservancy within the Greater Mara Region, Kenya. We conducted 73 timed counts in four distinct habitats (riparian, woodland, rocky outcrop and plains) in both dry and wet seasons. During this survey, we observed 188 species of birds of which 140 were recorded during the timed counts. The riparian zone had the highest species richness, more than three times that of the plains. The woodlands and rocky outcrops had similar species richness. The mean number of species seen per count was higher in the riparian zone compared with the other three habitats. Bird species composition in the riparian zone and the plains were distinct from each other and from the woodlands and rocky outcrops, although they overlapped significantly in the last two mentioned habitats. The possible conservation implication of an increasing and/or immigrant elephant population and its likely effect on the vegetation is discussed in relation bird community composition.

Keywords: bird community, Naboisho Conservancy, Masai Mara, habitat associations

\section{Introduction}

Savannas are globally important ecosystems of great significance to human economies. In Africa, savannas cover a significant portion of the continent and are host to a diverse assemblage of bird species (Sankaran et al. 2005). The drivers of African savannas are relatively well known, the most important of which include rainfall, fire, soils and herbivory (Scholes and Walker 1993). Of these, only fire and herbivory are likely to change at a particular locality within the short term, and both are amenable to some degree of human interference and control (Scholes and Walker 1993). Savanna ecosystems in East Africa are rarely stable and can experience rapid local changes from dense woodlands to open plains (Birkett and Stevens-Wood 2005). Despites numerous studies showing associations between birds and vegetation (e.g. Lack 1987, Skowno and Bond 2003, Sirami and Monadjem 2012), the influence of vegetation structure on avian communities is not well understood (Gaston 2000). In African savannas, riparian zones typically harbour a greater species richness of birds than adjoining scrub or woodland (Lack 1987, Mondjem 2005). 
The Mara-Serengeti system harbours a diverse array of vertebrate species, the best known being the large mammals, including the large migratory herds of ungulates and associated predators (Serneels and Lambin 2001). The birds of the Mara-Serengeti ecosystem have received less attention, however basic species lists are available for the region, and some ecological studies have also been conducted (e.g. Sinclair et al. 2002, Virani et al. 2011). The avifauna of the Greater Mara Region is relatively well known in the Masai Mara National Reserve but is poorly known beyond its boundaries in the conservancies to the north of the reserve.

Bird species richness is high in the Greater Mara Region, with an official checklist of 566 species (Kennedy 2012). However, many of the species on this list occur in specific habitats (such as wetlands and forests) that are restricted within this region, in space and/or time. For example, no true forest patches occur within Mara Naboisho Conservancy, where this study was conducted. As a result, only 220 species of birds have been recorded at Mara Naboisho Conservancy (M. Virani personal observation). How these birds are distributed across the savanna landscape is not well known, and their habitat associations are typically based on anecdotal observations rather than quantitative surveys.

The objectives of this study were to: 1) compare species richness and diversity of birds inhabiting different habitats at Naboisho; and 2) compare bird species composition between these habitats.

Study area

The Mara Naboisho Conservancy (hereafter Naboisho). is situated in the Greater Mara Region (GMR), south-western Kenya. The conservancy borders the Masai Mara National Reserve, as well as the Olare Orok and OI Kinyei Conservancies. The conservancy aims to conserve biodiversity and simultaneously enhancing the livelihoods of the approximately 500 local Maasai landowners who leased the land in 2010 (Thompson et al., 2009). Naboisho is now the second largest conservancy in the region, covering just over 20,000 ha. Currently there are eight established conservancies north of the Masai Mara National Reserve with a total area of $1100 \mathrm{~km}^{2}$ (Crystal Courtney personal communication).

\section{Methods}

Four habitats were recognized at Naboisho (Figure 1). 1) Plains; open grasslands with at most the occasional bush or small tree extending above the grass canopy. This habitat covers much of the conservancy, and comprising wide open grasslands dominated by Themeda triandra and Pennisetum mezianum. Sparse trees like Balanites spp occasionally dotted the open plains. 2) Woodland; varying amount of woody tree cover and occurring in patches throughout the conservancy, and predominantly comprising Acacia gerardii and Commiphora africana. Other trees included Balanites spp. and Dichrostachys cinerea. Typically, this habitat consisted of short trees widely spaced within open grasslands. 3) Riparian; well-developed thickets and woodland along rivers and drainage lines comprising predominantly of tall standing Acacia xanthophloea and A. kirkii with shorter stands of Euclea, Albizia and Oleander species. There were also large crowned Ficus sycomorus trees found here. 4) Rocky outcrops; shrubs and thickets growing on rocky situations along ridges. Short shrubs and trees consisting of $A$. gerrardii and $A$. drepanolobium were the most dominant species here. 
A

B

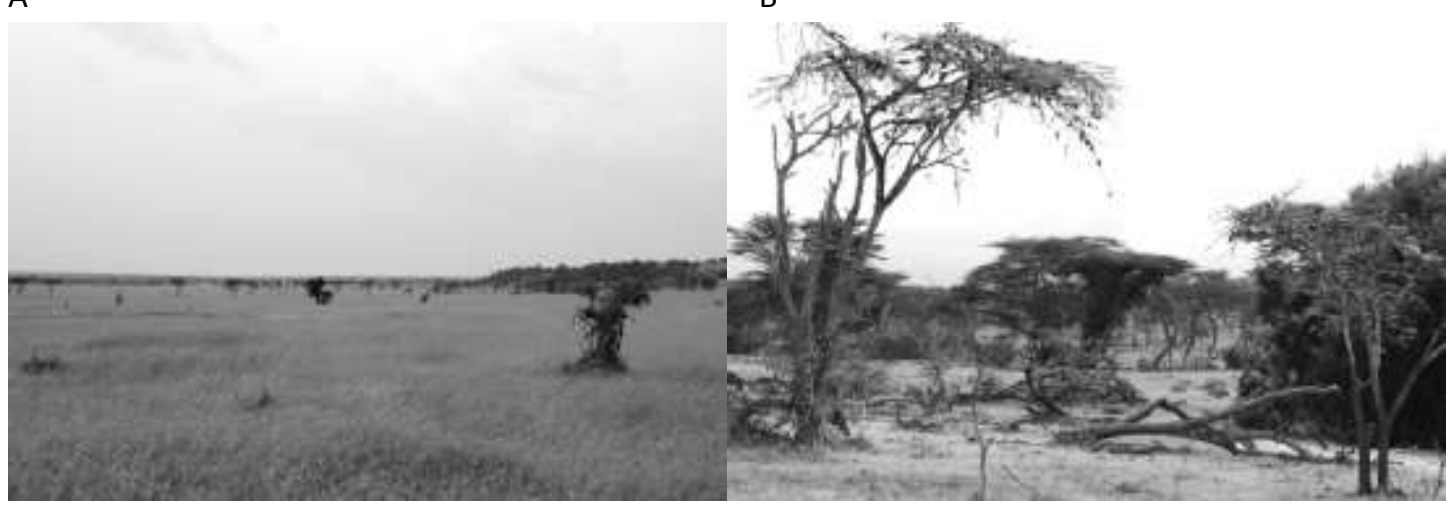

C

D

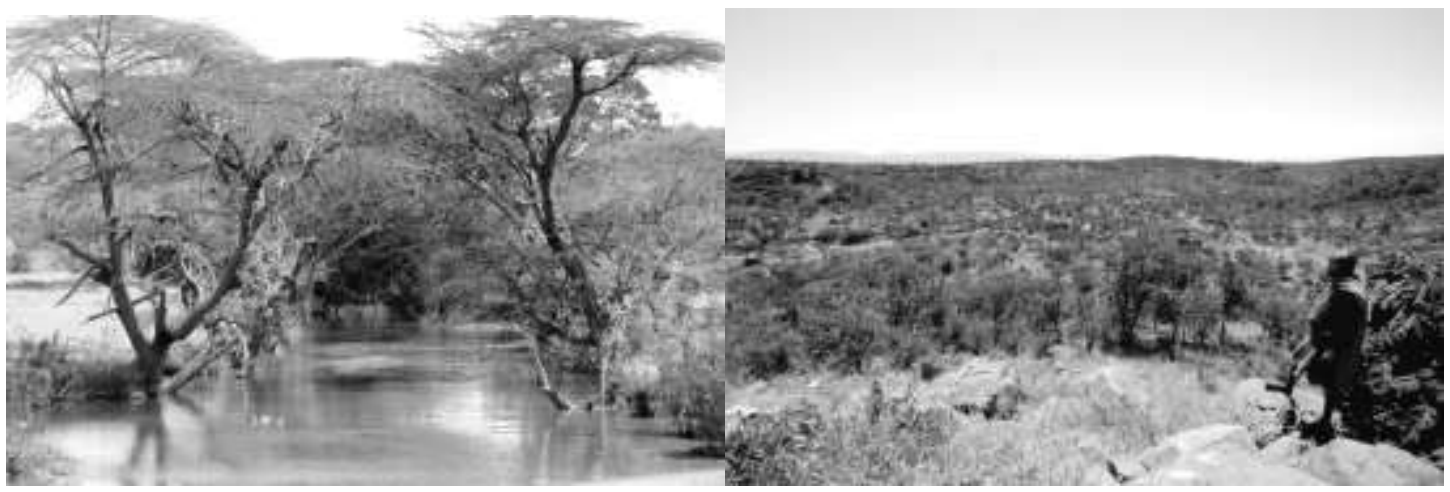

Figure 1: The four habitats recognized at Mara Naboisho Conservancy: A) plains; B) woodland; C) riparian; and D) rocky outcrops.

Bird surveys were conducted over a one week period in the dry season (October 2011), and repeated in the wet season (April 2012). A checklist for Naboisho Conservancy was prepared by recording every bird species seen during the entire survey. The bird community was surveyed by means of 50m fixed-radius timed point counts (Huto et al. 1986). We used a fixed width since we deemed this the best approach for maximizing our limited time spent locating birds at Naboisho. We took a GPS reading (using a Garmin eTrex) at the centre of each point, and we used the GPS to measure out $50 \mathrm{~m}$ from the centre allowing us to demarcate the boundary of the point. Timed counts were conducted over four mornings between 07:00 and 11:00 to maximize the chances of observing birds. A total of 73 timed counts were conducted in the four habitats. Each habitat was sampled at least three times and rotated in the order in which sampling began. So for example, if the wooded savanna habitat was sampled at 07:00 on the first day, then on the second day it was sampled at 08:30 and on the following day at 10:00 and so on. Each timed count was commenced once the two observers had arrived at the centre of a point. We counted all birds seen or heard, within a $50 \mathrm{~m}$ radius, during a 5 min period. When the time was up, we walked to the next point. We sampled eight points per habitat per day, and we visited three different habitats each day. where all birds observed over a five minute period were recorded over eight transect points per habitat spaced at least $200 \mathrm{~m}$ apart. To the best of our ability, we avoided the double counting of birds was avoided. This was only really an issue with the larger birds (such as raptors, hornbills, storks and francolins) that were capable of rapid long-distance movements. 
An Analysis of Variance (ANOVA) was used to compare mean species richness in the four habitats. A Tukey test was used to determine where the difference between the habitats laid. All statistical analyses were conducted in R ( $R$ Development Core Team 2010). All multivariate statistics were performed using the software package PRIMER (Clarke and Gorley 2001). Non-metric multidimensional scaling (MDS) was used to plot the 73 locations of the timed counts. Bray-Curtis similarities were computed on the square-root of the number of bird species recorded at each location, so as to down-weight the contributions of a few superabundant species in relation to rarer species (Clarke and Warwick 1994). ANOSIM (based on the Bray-Curtis similarities) was used to detect significant differences between the four habitats. Finally, SIMPER was used to determine which species contributed most to each of these four habitats.

\section{Results}

A total of 188 species of birds were recording during the two surveys, of which 104 were seen during the dry season visit and 102 in the wet season. Species accumulation curves for all the habitats combined and for each individual habitat showed upward trends without reaching an asymptote, although all the curves had started to taper off somewhat (Figure 2). Of these species, 140 (based on 743 individual sightings) were seen during the timed counts and all subsequent analyses are based on these data.

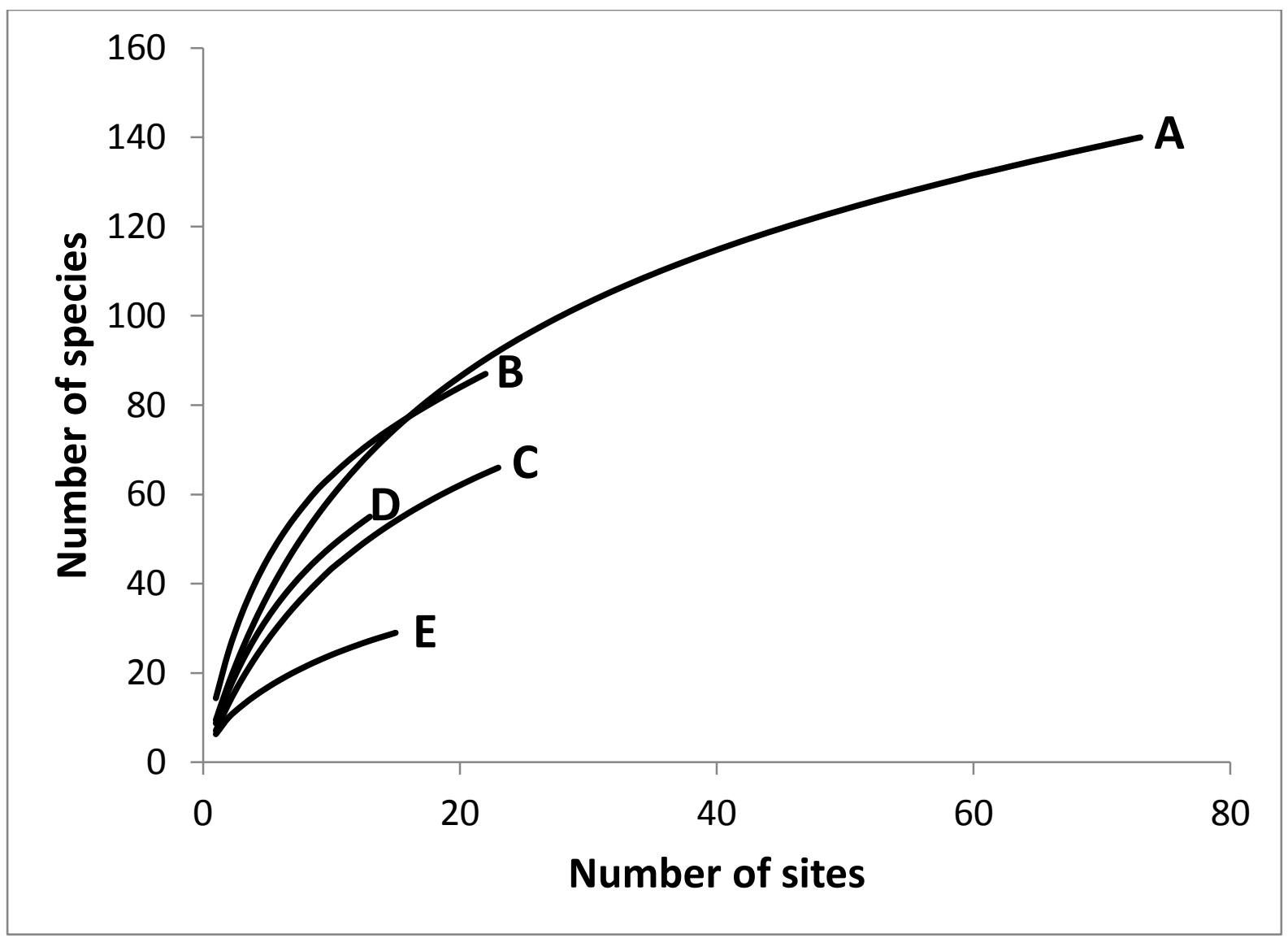

Figure 2: Species accumulation curves for birds at Naboisho showing: A) all records; B) riparian records; C) woodland records; D) rocky outcrop records; and E) plains records.

The riparian habitat had the highest species richness, followed by woodland, rocky outcrop and plains (Table 1). Mean number of species recorded per timed count was 10.2 across all four habitats. 
There were significant differences in the mean number of species recorded per timed count in these habitats $(F=16.74, D F=3,69, P<0.05$; Figure 3$)$. However, only the mean species richness of the riparian habitat was significantly different from any other habitat (Tukey test, $\mathrm{P}<0.05$ ); the remaining three habitats were not significantly different from each other (Tukey test, $P>0.05$ ).

Table 1: Number of species recorded in the four different habitats at Naboisho.

\begin{tabular}{lllll}
\hline & Riparian & Woodland & Rocky outcrop & Plains \\
\hline Number of species & 88 & 66 & 59 & 29 \\
Number of Red List species & 1 & 1 & 1 & 1 \\
\hline
\end{tabular}

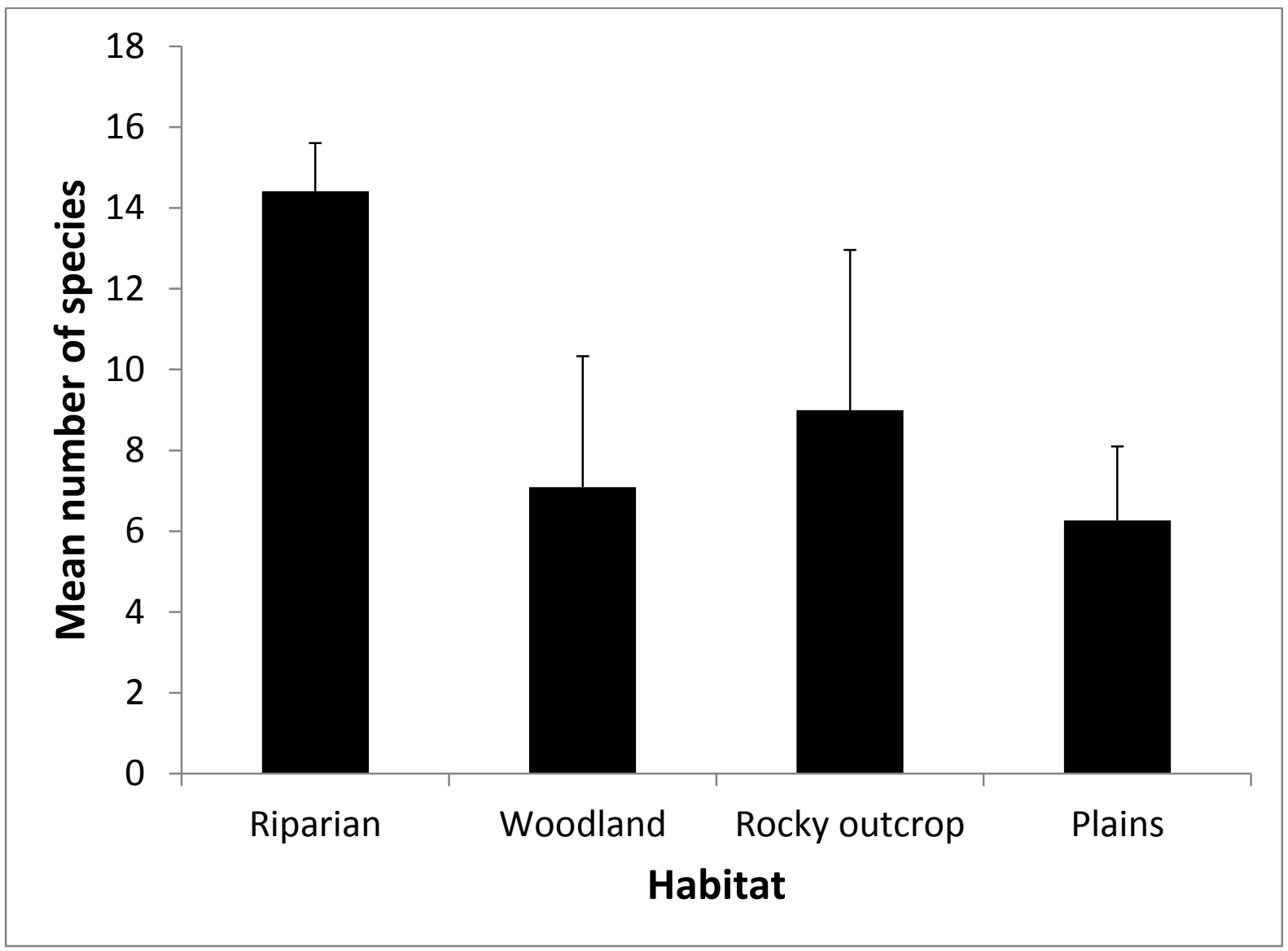

Figure 3: Mean number of bird species recorded per timed count in each of the four habitats at Naboisho.

MDS ordination of the 73 locations resulted in relatively good separation between the four habitats, namely riparian, woodland, rocky outcrops and plains (Figure 4). These four habitats differed significantly from each other with respect to their bird species communities (ANOSIM, R $=0.531, \mathrm{P}<$ 0.01). Between 13 and 19 bird species contributed $50 \%$ of the dissimilarity between the four habitats (Table 2). The plains were typically characterised by pipits, larks and cisticolas; whereas the riparian habitat was distinguished by a taxonomically diverse group of birds typically associated with thickets and gallery woodland such as Cossypha heuglini, Laniarius funebris and Apalis flavida. The distinction between the bird community associated with woodland and rocky outcrops was not as clear as that between other habitats. 
Table 2: Species contributing a cumulative $66 \%$ of the dissimilarity between the four habitats at Naboisho. Species are listed in order of importance.

\begin{tabular}{|c|c|c|c|c|c|}
\hline Riparian/Woodland & Riparian/Rocks & Riparian/Plains & Woodland/Rocks & Woodland/Plains & Rocks/Plains \\
\hline $\begin{array}{l}\text { Psalidoprocne } \\
\text { fuliginosa }^{\mathrm{a}}\end{array}$ & $\begin{array}{l}\text { Psalidoprocne } \\
\text { fuliginosa }^{\mathrm{a}}\end{array}$ & $\begin{array}{l}\text { Psalidoprocne } \\
\text { fuliginosa }^{\mathrm{a}}\end{array}$ & $\begin{array}{l}\text { Cinnyris } \\
\text { mariquensis }^{c}\end{array}$ & $\begin{array}{l}\text { Cisticola } \\
\text { brunnescens }^{\mathrm{d}}\end{array}$ & Mirafra africana ${ }^{\mathrm{d}}$ \\
\hline $\begin{array}{l}\text { Cinnyris } \\
\text { mariquensis }^{\mathrm{a}}\end{array}$ & $\begin{array}{l}\text { Cinnyris } \\
\text { mariquensis }^{\mathrm{a}}\end{array}$ & $\begin{array}{l}\text { Mirafra } \\
\text { africana }^{\mathrm{d}}\end{array}$ & Cisticola chiniana $^{\mathrm{c}}$ & Hirundo rustica $^{\mathrm{d}}$ & $\begin{array}{l}\text { Cisticola } \\
\text { brunnescens }^{d}\end{array}$ \\
\hline Cisticola chiniana $^{\mathrm{b}}$ & $\begin{array}{l}\text { Cisticola } \\
\text { chiniana }^{a}\end{array}$ & $\begin{array}{l}\text { Cisticola } \\
\text { brunnescens }^{d}\end{array}$ & $\begin{array}{l}\text { Streptopelia } \\
\text { capicola }^{\mathrm{b}}\end{array}$ & Mirafra africana $^{\mathrm{d}}$ & Hirundo rustica $^{\mathrm{d}}$ \\
\hline Cossypha heuglini ${ }^{\mathrm{a}}$ & $\begin{array}{l}\text { Laniarius } \\
\text { funebris }^{a}\end{array}$ & Hirundo rustica $^{\mathrm{d}}$ & Dicrurus adsimilis $^{\mathrm{c}}$ & $\begin{array}{l}\text { Vanellus } \\
\text { coronatus }^{\mathrm{d}}\end{array}$ & $\begin{array}{l}\text { Vanellus } \\
\text { coronatus }^{d}\end{array}$ \\
\hline Laniarius funebris $^{\mathrm{a}}$ & $\begin{array}{l}\text { Cossypha } \\
\text { heuglini }\end{array}$ & $\begin{array}{l}\text { Cinnyris } \\
\text { mariquensis }^{a}\end{array}$ & Laniarius funebris $^{\mathrm{c}}$ & $\begin{array}{l}\text { Anthus } \\
\text { cinnamomeus }^{\mathrm{d}}\end{array}$ & $\begin{array}{l}\text { Cinnyris } \\
\text { mariquensis }^{c}\end{array}$ \\
\hline $\begin{array}{l}\text { Camaroptera } \\
\text { brachyura }^{a}\end{array}$ & $\begin{array}{l}\text { Dicrurus } \\
\text { adsimilis }^{\mathrm{c}}\end{array}$ & $\begin{array}{l}\text { Vanellus } \\
\text { coronatus }^{\mathrm{d}}\end{array}$ & Batis molitor $^{\mathrm{b}}$ & Cisticola chiniana $^{\mathrm{b}}$ & $\begin{array}{l}\text { Anthus } \\
\text { cinnamomeus }^{\mathrm{d}}\end{array}$ \\
\hline $\begin{array}{l}\text { Pycnonotus } \\
\text { barbatus }^{a}\end{array}$ & $\begin{array}{l}\text { Pycnonotus } \\
\text { barbatus }^{a}\end{array}$ & $\begin{array}{l}\text { Laniarius } \\
\text { funebris }^{\mathrm{a}}\end{array}$ & Francolinus coqui $^{\mathrm{c}}$ & Batis molitor $^{\mathrm{b}}$ & $\begin{array}{l}\text { Cisticola } \\
\text { chiniana }^{c}\end{array}$ \\
\hline Batis molitor & $\begin{array}{l}\text { Francolinus } \\
\text { coqui }^{\text {a }}\end{array}$ & $\begin{array}{l}\text { Cisticola } \\
\text { chiniana }^{\mathrm{b}}\end{array}$ & Mirafra africana & $\begin{array}{l}\text { Streptopelia } \\
\text { capicola }^{\mathrm{b}}\end{array}$ & $\begin{array}{l}\text { Dicrurus } \\
\text { adsimilis }^{c}\end{array}$ \\
\hline $\begin{array}{l}\text { Streptopelia } \\
\text { capicola }^{\text {b }}\end{array}$ & $\begin{array}{l}\text { Streptopelia } \\
\text { capicola }^{c}\end{array}$ & $\begin{array}{l}\text { Anthus } \\
\text { cinnamomeus }^{\mathrm{d}}\end{array}$ & $\begin{array}{l}\text { Turtur } \\
\text { chalcospilos }^{c}\end{array}$ & Anthus similis $^{\mathrm{d}}$ & $\begin{array}{l}\text { Laniarius } \\
\text { funebris }^{c}\end{array}$ \\
\hline Francolinus coqui $^{\mathrm{a}}$ & $\begin{array}{l}\text { Chalcomitra } \\
\text { senegalensis }^{\text {a }}\end{array}$ & $\begin{array}{l}\text { Cossypha } \\
\text { heuglini }\end{array}$ & Hirundo rustica ${ }^{c}$ & $\begin{array}{l}\text { Coracias } \\
\text { caudatus }^{\mathrm{d}}\end{array}$ & Anthus similis $^{\mathrm{d}}$ \\
\hline Gyps africanus $^{\mathrm{a}}$ & Apalis flavida ${ }^{\mathrm{a}}$ & $\begin{array}{l}\text { Camaroptera } \\
\text { brachyura }^{\mathrm{a}}\end{array}$ & $\begin{array}{l}\text { Lamprotornis } \\
\text { superbus }^{\mathrm{c}}\end{array}$ & Cisticola juncidis $^{\mathrm{d}}$ & $\begin{array}{l}\text { Turtur } \\
\text { chalcospilos }^{c}\end{array}$ \\
\hline $\begin{array}{l}\text { Cercotrichas } \\
\text { leucophrys }^{a}\end{array}$ & Gyps africanus ${ }^{\mathrm{a}}$ & $\begin{array}{l}\text { Pycnonotus } \\
\text { barbatus }^{a}\end{array}$ & $\begin{array}{l}\text { Serinus } \\
\text { dorsostriatus }^{c}\end{array}$ & $\begin{array}{l}\text { Terathopius } \\
\text { ecaudatus }^{d}\end{array}$ & Cisticola juncidis $^{\mathrm{d}}$ \\
\hline $\begin{array}{l}\text { Chalcomitra } \\
\text { senegalensis }^{\mathrm{a}}\end{array}$ & $\begin{array}{l}\text { Cercotrichas } \\
\text { leucophrys }^{a}\end{array}$ & $\begin{array}{l}\text { Francolinus } \\
\text { coqui }^{\mathrm{a}}\end{array}$ & $\begin{array}{l}\text { Bradornis } \\
\text { microrhynchus }\end{array}$ & $\begin{array}{l}\text { Lamprotornis } \\
\text { hildebrandti }^{\mathrm{b}}\end{array}$ & $\begin{array}{l}\text { Terathopius } \\
\text { ecaudatus }^{d}\end{array}$ \\
\hline Mirafra africana ${ }^{\mathrm{b}}$ & $\begin{array}{l}\text { Pogoniulus } \\
\text { pusillus }^{a}\end{array}$ & Gyps africanus $^{a}$ & $\begin{array}{l}\text { Lamprotornis } \\
\text { purpuroptera }^{\mathrm{c}}\end{array}$ & & $\begin{array}{l}\text { Francolinus } \\
\text { coqui }^{\mathrm{c}}\end{array}$ \\
\hline Apalis flavida $^{\mathrm{a}}$ & Batis molitor $^{\mathrm{a}}$ & $\begin{array}{l}\text { Chalcomitra } \\
\text { senegalensis }^{\mathrm{a}}\end{array}$ & Crombec whytii & & \\
\hline $\begin{array}{l}\text { Corythaixoides } \\
\text { personatus }^{\mathrm{a}}\end{array}$ & Hirundo rustica $^{c}$ & $\begin{array}{l}\text { Cercotrichas } \\
\text { leucophrys }^{\mathrm{a}}\end{array}$ & $\begin{array}{l}\text { Pycnonotus } \\
\text { barbatus }^{c}\end{array}$ & & \\
\hline Pogoniulus pusillus ${ }^{\mathrm{a}}$ & $\begin{array}{l}\text { Turtur } \\
\text { chalcospilos }^{c}\end{array}$ & Anthus similis $^{\mathrm{d}}$ & Tockus deckeni & & \\
\hline Hirundo rustica $^{\mathrm{a}}$ & $\begin{array}{l}\text { Dendropicos } \\
\text { goertae }^{\mathrm{a}}\end{array}$ & $\begin{array}{l}\text { Pogoniulus } \\
\text { pusillus }^{\mathrm{a}}\end{array}$ & Apalis flavida ${ }^{\mathrm{C}}$ & & \\
\hline Dicrurus adsimilis $^{\mathrm{a}}$ & $\begin{array}{l}\text { Rhinopomastus } \\
\text { minor }^{c}\end{array}$ & & & & \\
\hline $\begin{array}{l}\text { Halcyon chelicuti } \\
\text { Terpsiphone viridis }^{\mathrm{a}} \\
\text { Halcyon } \\
\text { leucocephala }^{\mathrm{a}}\end{array}$ & Crombec whytii ${ }^{\mathrm{C}}$ & & & & \\
\hline \multicolumn{6}{|c|}{ a predominantly in riparian } \\
\hline \multicolumn{6}{|c|}{ b predominantly in woodland } \\
\hline \multicolumn{6}{|c|}{ cpredominantly in rocky outcrops } \\
\hline${ }^{d}$ predominantly in pla & & & & & \\
\hline
\end{tabular}




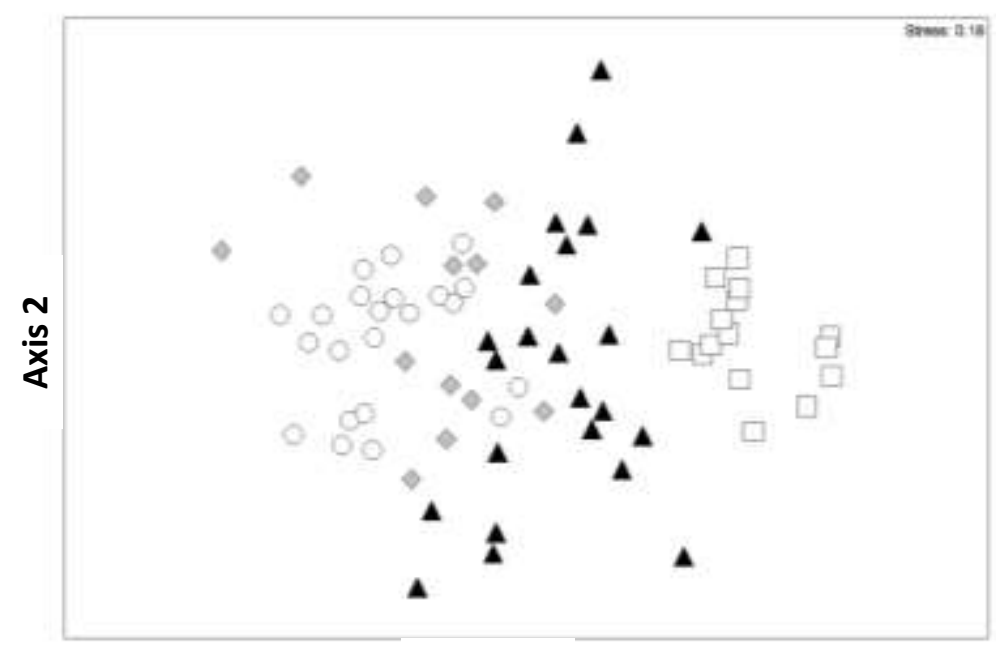

Axis 1

Figure 4: Non-metric multidimensional scaling of the 73 locations using timed counts of birds. Open squares = woodland; gray diamonds = rocky outcrops; open circles = riparian; and filled triangles = plains.

\section{Discussion}

We emphasize that this study was by no means an exhaustive survey of the birds of Naboisho; something that is not possible in the short timeframe of this study. In fact, the 188 species recorded during the study period represent just $64 \%$ of the 220 species on the official, but unpublished, Naboisho checklist (M. Virani, personal observation). This is further corroborated by the fact that the species accumulation curve (Figure 2) had not yet reached an asymptote. However, this study aimed to elucidate the habitat associations of the birds at Naboisho, and for this purpose, the data are adequate.

The four habitats at Naboisho support different bird communities, with those of the plains being the most distinct. The plains typically supported a species-poor assemblage of mostly ground-dwelling birds such as pipits, larks and cisticolas (Table 2, Appendix 1). This association is not surprising as these are typical grassland birds, foraging on the ground and nesting either on the ground or low down within the grass layer. The plains are structurally the simplest of the habitats at Naboisho, resulting in fewer niches being available, and hence fewer bird species occupying this habitat. The riparian zone supports a structurally complex habitat, with a diverse bird community associated with it. Similar observations were made at Tsavo National Park in eastern Kenya (Pearson and Lack 1992).

The mean number of species recorded during the timed counts was higher only for the riparian zone; the other three habitats did not differ significantly in this regard. This is at first glance rather surprising, considering the far higher species richness in the woodlands and rocky outcrops than in the plains (Table 1). This suggests that at the scale of a timed count (less than 1 ha), the number of bird species supported by these three habitats is similar. The higher diversity in woodland and rocky outcrop therefore can be explained by a greater turnover in these habitats as one moves across the landscape at a higher scale (for example over 10 ha or more). Within the plains, however, the same species occur throughout with little, or no, turnover at the same scale. The higher mean number of species recorded in the riparian zone may be related to the greater structural diversity of this habitat (Monadjem 2005). 
There are possible conservation implications of this study, the most obvious one being the potential effect of increasing elephant numbers in the region. Although the Greater Mara Region has experienced a decline in its non-migratory herbivore populations (Ogutu et al., 2011), the number of elephants in the region have remained stable and the creation of new wildlife conservancies with tracts of undisturbed woodland has resulted in a large number of elephants using this relatively "newer" habitat (Ottichilo et al., 2000). The negative relationship between elephant numbers and woody biomass has been well established across Africa (Dublin et al,, 1990). As a result, the Serengeti has experienced a gradual opening up of its wooded habitats as trees get pushed over by elephants at a faster rate than they can regenerate. In Laikipia County of Kenya, Acacia drepanlobium trees were monitored from 1998 to 2001, a period that included 12 months when rainfall was $60 \%$ below average and elephants were responsible for the loss of $40 \%$ of the trees (Birkett and Stevens-Wood 2005). These findings have implications for research into the causes of instability in savanna ecosystems and the management of enclosed reserves. Pellew (1983) showed that elephants were largely responsible for the damage of Acacia tortilis trees in the Seronera grasslands of the Serengeti at an annual rate of $6 \%$.

What happens to the bird community during such a transition has not yet been documented and this study is an exploratory approach towards getting a better understanding of how vegetation dynamics of the Mara-Serengeti ecosystem affects avifaunal communities. Sirami and Monadjem (2012) showed that as woody vegetation in the form of bush encroachment increased, grassland birds disappeared and were replaced by birds associated with thickets. We suspect that the reverse of this pattern will be shown in Naboisho in the next decade or two, with grassland birds replacing woodland and thicket birds. This is particularly worrying since the birds associated with plains in Naboisho constitute only a small number of widely distributed and abundant species, none of which are currently threatened with extinction. In contrast, the nine near threatened and threatened species of birds recorded during this survey were all raptor species that breed in large trees, predominantly in the riparian zone. Hence, we recommend that the bird community at Naboisho be closely monitored over the next decade to determine whether such expected changes are observed or not. Birds have been widely regarded as a key element in monitoring biodiversity to assess ecosystem health. We believe that while birds are unlikely to be an umbrella or indicator taxon for other biota (other vertebrates, invertebrates, plants, micro-organisms), they do represent a taxon that can be efficiently and inexpensively monitored. At Naboisho, there is the capacity to mobilize local Maasai guides to undertake bird surveying. While there are many limitations to acquiring highquality information (scale, dynamism, mobility, paucity of observers over much of the rangelands), we think that these can be dealt with sufficiently well to justify the use of birds as a key component of biodiversity monitoring for conservancies.

\section{Acknowledgements}

We gratefully thank the following organisations and people for assistance with logistics and fieldwork: Base Camp Foundation, Mara Naboisho Conservancy, Ol Kinyei Conservancy, Narok County, Senior Warden, Masai Mara National Reserve, Hitesh Mehta, Dickson Ole Kaelo, Justin Heath, Lars Lindvist, and Nils Morgensen. 


\section{References}

Birkett A, \& Stevens-Wood B. 2005. Effect of low rainfall and browsing by large herbivores on an enclosed savannah habitat in Kenya. African Journal of Ecology 43: 123-130. doi.org/10.1111/j.1365-2028.2005.00555.x

Clarke KR, Gorley RN. 2001. Primer, version 5: use manual/tutorial. Primer-E Ltd, Plymouth.

Clarke KR, Warwick RM. 1994. Change in marine communities: an approach to statistical analysis and interpretation. Natural Environment Research Council, UK.

Dublin HT, Sinclair ARE, McGlade J. 1990. Elephants and Fire as Causes of Multiple Stable States in the Serengeti-Mara Woodlands. Journal of Animal Ecology 59: 1147-1164. doi.org/10.2307/5037.

Gaston KJ. 2000. Global patterns in biodiversity. Nature 405: 220-227. doi.org/10.1038/35012228

Hutto RL, Pletschet SM, Hendricks P. 1986. A Fixed-Radius Point Count Method for Nonbreeding and Breeding Season Use. The Auk 103: 593-602.

Kennedy AS. 2012. Bird check list. In Maasai Mara. Africa's greatest wildlife reserve (du Toit J, Withey A eds). ORD Group Limited, Nairobi.

Lack PC. 1987. The structure and seasonal dynamics of the bird community in Tsavo East National Park, Kenya. Ostrich 58 : 9-23.

Monadjem A. 2005. Association between avian communities and vegetation structure in a low-lying woodland-savanna ecosystem in Swaziland. Ostrich 76: 45-55.

Ogutu JO, Owen-Smith N, Piepho H-P, Said MY. 2011. Continuing wildlife population declines and range contraction in the Mara region of Kenya during 1977-2009. Journal of Zoology 85: 99-doi.org/10.1111/j.1469-7998.2011.00818.x

Ottichilo WK, De Leeuw J, Skidmore AK, Prins HHT, Said MY. 2000. Population trends of large non-migratory wild herbivores and livestock in the Masai Mara ecosystem, Kenya, between 1977 and 1997. African Journal of Ecology 38: 202216. doi.org/10.1046/j.1365-2028.2000.00242.x

Pellew RAP. 1983. The impacts of elephant, giraffe and fire upon the Acacia tortilis woodlands of the Serengeti. African Journal of Ecology 21: 41-74. doi.org/10.1111/j.1365-2028.1983.tb00311.x

R Development Core Team. 2010. R: A language and environment for statistical computing. R Foundation for Statistical Computing, Vienna, Austria.

Sankaran M, Hanan NP, Scholes RJ, Ratnam J, Augustine DJ, Cade BS, Zambatis N. 2005. Determinants of woody cover in African savannas. Nature 438: 846-849. doi.org/10.1038/nature04070

Scholes RJ, Walker BH. 1993. An African Savanna. Cambridge University Press, Cambridge

Serneels S, Lambin EF. 2001. Impact of land-use changes on the wildebeest migration in the northern part of the Serengeti-Mara ecosystem. Journal of Biogeography 28: 391-407.

Sinclair ARE, Arces P (eds). 1995. Serengeti II: dynamics, management and conservation of an ecosystem. Chicago University Press.

Sinclair ARE, Mduma SAR, Arcese P. 2002. Protected areas as biodiversity benchmarks for human impacts: agriculture and the Serengeti avifauna. Proceedings of the Royal Society of London, Series B 269: 2401-2405.

Sirami C, Monadjem A. 2012. Changes in bird communities in Swaziland savannas between 1998 and 2008 owing to shrub encroachment. Diversity \& Distributions 18: 390-400.

Skowno AL, Bond WJ. 2003. Bird community composition in an actively managed savanna reserve, importance of vegetation structure and vegetation composition. Biodiversity and Conservation 12: 2279-2003.

Thompson M, Serneels S, Kaelo D, Trench P. 2009. 'Maasai Mara - land privatization and wildlife

decline: Can conservation pay its way?', in Homewood K, Kristjanson P and Chevenix Trench P (eds), Staying Maasai? Livelihoods, Conservation and Development in East African Rangelands. Springer: New York.

Virani MZ, Kendall C, Njoroge P, Thomsett S. 2011. Major declines in the abundance of vultures and other scavenging raptors in and around the Masai Mara ecosystem, Kenya. Biological Conservation 144: 746-752.

doi.org/10.1016/j.biocon.2010.10.024 